\title{
Identification and Evaluation of Environmental Pollution Damage of a Red Mud Reservoir
}

\author{
Xin $\mathrm{LU}^{1} \&$ Qing-Min ZHANG ${ }^{2} \&$ Xiang-Hua LI*3, Yu SONG ${ }^{4}$ \\ ${ }^{123}$ Henan Academy of Environment Protection ,Zhengzhou, China \\ ${ }^{4}$ Henan Agricultural University, Zhengzhou, China
}

KEYWORD: Red mud leak; Environmental pollution Damage; Identification; Evaluation

\begin{abstract}
To comprehensively investigate the environmental responsibility of polluters, there is an urgenneed to implement the policy against illegal discharge and meet the environmental challenges in carrying out the environmental pollution damage assessment. This paper studies the environmental pollution events caused by a Red Mud Reservoir incident, analyzes the pollutant properties, the time range and spatial scope of the pollutants, and then examine the environmental damage assessment from four aspects including agricultural and forestry products damage, soil environmental damage and emergency disposal costs. The environmental damage caused by the incident was assessed, with a view to provide a reference for future environmental damage assessment of similar pollution incidents.
\end{abstract}

\section{INSTRUCTION}

In recent years, the frequent occurrence of environmental pollution damage has become a hidden danger that affects the life and the safety of citizens, and even the whole country's economic and social development. Environmental pollution and the resulting environmental infringement disputes have gradually become a major social problem in China.

In 2011, the Ministry of Environmental Protection (MEP) issued a number of Opinions on Conducting Environmental Pollution Damage Assessment and Evaluation (Huan Fa [2011] No. 60) in order to deal with the severe environmental situation and properly resolve environmental infringement disputes arising from environmental pollution. To carry out environmental pollution damage identification and assessment work, a comprehensive investigation of the environmental responsibility of polluters has been conducted. Subsequently, the Ministry of Environmental Protection issued "Environmental Damage Assessment and Recommendation Method ( II )" (Central Office [2014] 90), standardized assessment of environmental pollution damage assessment of the technical methods. Though some scholars have done some preliminary research in this field, the assessment of environmental damage in our country is still in the exploration stage. The related cases are still lacking and technical methods need to be improved. In order to further explore the environmental damage appraisal method in specific areas, the evaluation of environmental pollution damage of a red mud leak is thus studied to provide reference for future environmental pollution damage assessment of similar pollution incidents.

\section{THE INCIDENCE AND DETAILS OF THE INCIDENT}

A continuous heavy rain occurred in City A during September 2014. On September 16, the eddy was formed close to the dam on the northern part of a red mud reservoir. Piping burst took place immediately. Then the soil near the pipe collapsed and escalated very fast. Approximately one hour later, the dam was completely collapsed and a large number of red mud slurry leaked and ditched down, spreading about $50 \mathrm{~m}$ along the dam downstream.

After the incident, the relevant departments quickly started contingency plans to carry out emergency work, and immediately organized personnel reinforcement in the valley downstream of the B reservoir waste dam as a No. 2 emergency dam, blocking wastewater. 3:00 or so, 2 emergency dam overtopping. Relevant departments immediately in the 2 emergency dam downstream $2 \mathrm{~km}$ at the construction of emergency response on the 3rd, about 5:00 pm on the 3rd emergency dam overtopping dam. Relevant departments and immediately organized personnel in the 3rd emergency dam downstream $600 \mathrm{~m}$ (near the railway bridge) at the construction of emergency response on the 4th to ensure red mud was divided into blocks in the emergency 
between the dam. As the rainfall was too large, about 8:00 or so, red mud from the emergency side of the dam under the side of leakage along the natural ditch $450 \mathrm{~m}$ downstream into the $\mathrm{C}$, and then along the C River down $2.4 \mathrm{~km}$ into the D River. To minimize the effect on the water quality of the D River , the relevant departments immediately organized personnel in the emergency discharge dam under the No. 4 filling sulfuric acid, to ensure that the wastewater into the D River to meet the relevant standards.

After all levels of government and relevant departments, a company for 10 days and nights of the parties fighting, as of September 25 12:00, the leakage gap plugging completed, red mud on the way to discharge red mud and alkaline water was still in the treatment of in.

\section{SCOPE DEFINITION}

\subsection{Determination of pollutant properties}

In this environmental damage assessment, the leakage of red mud, alkaline water into pieces in the environment, it becomes a source of pollution caused by environmental damage. The potential environmental damage caused by this source of pollution there are two, namely:

Section 1 Potential Environmental Damage Source: Damage occurred between the red mud yard of the company's dam 2 and the lower reservoir between the No. 1 dam (under construction) and the detention area after the red mud leakage event Red mud and the surface of stagnant alkaline water;

The second potential source of environmental damage: 1 dam (under construction) to 4 between the emergency dam, the dam-breaking event after the accident on the way to stay red mud and the surface of stagnant alkaline water.

According to the results of field monitoring and historical monitoring of a company, the red mud and liquid substances distributed in the environment damaged areas are all corrosive substances. According to "Identification Criteria of Hazardous Wastes - Corrosion Identification" (GB 5085.12007), it can be determined that they were hazardous waste, environmental hazards.

\subsection{Determination of the amount of pollutants}

In the emergency phase of the preliminary estimate of this event, the leaking red mud was about $3000 \mathrm{~m}^{3}$, the cumulative discharge of red mud water was about $383,100 \mathrm{~m}^{3}$.In the emergency phase and after a number of on-site investigation, field measurements, calculations, the initial assessment that the red mud leaked was about $30718.46 \mathrm{~m}^{3}$, the cumulative discharge of red mud water was about $383100 \mathrm{~m}^{3}$.

\subsection{Time limit}

The time scale of environmental damage assessment varies according to the type of damage. The time frame for the appraisal of property damage shall be determined according to the specific circumstances such as the object of damage, the nature of the damage and the way of compensation. The time scale of ecological environmental damage assessment starts from the date of pollution or ecological behavior destruction, and continues until the damaged ecological environment and its ecosystem services return to the baseline of ecological environment. The time for the assessment of the emergency treatment costs shall start from the date of occurrence of the emergency environmental incident and shall continue until the emergency disposal end date. 
Table1 Possible time ranges and finalized time ranges for this evaluation

\begin{tabular}{ccc}
\hline Damage type & Possible time range & $\begin{array}{c}\text { Finalized } \\
\text { time frame }\end{array}$ \\
\hline Property damage & $\begin{array}{c}\text { According to the damage object, the nature of damage } \\
\text { and compensation to determine the specific circumstances } \\
\text { Effective September 16, 2014, until the damaged soil } \\
\text { environment and its ecosystem services are restored to } \\
\text { groundwater environmental baselines } \\
\text { damage }\end{array}$ & $\begin{array}{c}\text { As of } \\
\text { Oner 2014 } \\
\text { 4-6 years }\end{array}$ \\
$\begin{array}{c}\text { Expenditure on } \\
\text { Emergency Handling } \\
\begin{array}{c}\text { Other transactional } \\
\text { expenses }\end{array}\end{array}$ & Until November 25, 2014 \\
\hline
\end{tabular}

\subsection{Spatial extent}

In this environmental damage, the possible scope of personal injury, property damage or ecological environment damage can be initially determined by means of site investigation, environmental monitoring, biological monitoring, model prediction or remote sensing analysis (such as aerial photograph, satellite image). Based on those basic information input, environmental damage recognition and causal identification was carried out, and we ultimately determine the property damage, damage to the environment and costs of the accident including emergency response and other transaction costs.

Table 2 The possible spatial extent of this assessment and the finalized spatial scope

\begin{tabular}{|c|c|c|}
\hline Damage type & $\begin{array}{l}\text { Possible } \\
\text { spatial } \\
\text { extent }\end{array}$ & The final determination of the spatial extent \\
\hline Property damage & A City & $\begin{array}{l}\text { (1) A city E card, involving } 570 \text { households, } 2170 \\
\text { people; (2) A City F Town, involving } 110 \text { households }\end{array}$ \\
\hline $\begin{array}{l}\text { Soil environmental } \\
\text { damage }\end{array}$ & $\begin{array}{l}\text { A town, B } \\
\text { town }\end{array}$ & $\begin{array}{c}\text { B reservoir upstream of } 110.80 \text { acres of shrub forest and } \\
\text { its downstream } 302.84 \text { acres of farmland, } 61.87 \text { acres of } \\
\text { nursery soil and other areas }\end{array}$ \\
\hline $\begin{array}{c}\text { Expenditure on } \\
\text { Emergency Handling }\end{array}$ & A City & A City and its subordinate A town, B town \\
\hline $\begin{array}{l}\text { Other transactional } \\
\text { expenses }\end{array}$ & A City & A City and its subordinate A town, B town \\
\hline
\end{tabular}

\section{DAMAGE ASSESSMENT}

\subsection{Property Damage Assessment}

Property damage assessment includes property damage caused by this event (except agricultural and forestry products property), such as loss of value of fixed assets and loss of current assets.

(1) Loss of fixed assets

It refers to the damage caused by pollution of the environment or destruction of ecological behavior caused by fixed assets or reduce the value of the loss, the use of repair cost method or replacement cost method. For the total damage, the replacement cost method is used; while for part of the damage, replacement cost method or repair cost method is used.

(2) Loss of current assets 
Refers to the production and operation process to participate in the cycle of turnover, changing its form of assets, such as raw materials, materials, fuel, in-process products, semi-finished products, finished products and other economic losses.

After the on-site consultation, inspection, data collection, according to the assessment of the accident in the road, water conservancy facilities, electrical facilities, recreational and other damage to the full range of comprehensive assessment, the final determination of the amount of property damage is 32.534 million yuan.

\subsection{Damage assessment of agricultural and forestry products}

The appraisal and assessment of property damage of agroforestry products covers $302.84 \mathrm{mu}$ of farmland (mainly wheat and corn rotation) in E town and $61.87 \mathrm{mu}$ of nursery. According to soil monitoring results showing that red mud leakage caused by local environmental damage, the main performance is the soil $\mathrm{pH}$, soil salinity, water-soluble sodium increased, resulting in plants death due to excessive salt and water loss. Damage assessment of agricultural and forestry products mainly based on the actual area of damage, yield per unit area and the market price of agricultural products to determine the current economic losses.

This assessment confirms that this environmental damage incident caused damage to agricultural and forestry products in the region. During this period, the loss of agricultural and forestry products in the region can be identified as causal relationship with the environmental damage incident. After the assessment personnel on-site consultation, according to the evaluation method, the farmland, nursery and farmland shelterbelts in this accident were evaluated comprehensively and comprehensively. The total cost of agricultural and forestry product damage was 4.33 million yuan.

\subsection{Assessment of Soil Environmental Damage}

According to the Working Procedure for Pollution Accident Assessment in Emergency Response Period (Huan Fa [2013] No. 85), the cost of soil remediation refers to the costs of remediation measures taken to identify contaminated soils, including the establishment of remediation plan, and all costs incurred in the later period of supervision.

Site remediation costs are determined first according to the Recommended Method for Environmental Damage Calculation, and then the cost of repairing the site is estimated.

According to the evaluation method, the farmer, nursery and shrub soil in this accident were evaluated comprehensively and comprehensively, and the total cost of soil environmental damage was determined to be 131.092 million yuan.

\subsection{Assessment of contingency costs}

The emergency response phase of this incident began on September 16, 2014 and ended at 12:00 on September 25, 2014.

Emergency treatment costs include emergency treatment phase pollution control, pollution clean-up, emergency monitoring, personnel placement and other types of emergency measures arising from the sum of the costs.

$$
V=V_{1}+V_{2}+V_{3}+V_{4}+V_{5}
$$

$V$-Emergency disposal expenses;

$V_{1}$-Pollution control costs;

$V_{2}$-Pollution cleanup costs;

$V_{3}$-Emergency monitoring costs;

$V_{4}$ - Personnel of relocation expenses;

$V_{5}$-Other action costs

After field investigation and collection of information to confirm the relevant circumstances of this incident emergency treatment phase, combined with the collection of emergency response phase of the participating units of the contingency cost assessment form and the relevant supporting 
materials, according to the assessment method of emergency incident costs to confirm and audit, and ultimately determine the incident cost of 15.803 million yuan in emergency treatment.

\section{CONCLUSION}

The total cost of damage to the property was 32.534 million yuan, the total cost of damage to agricultural and forestry products was 4.33 million yuan, the total cost of soil environmental damage was 131.092 million yuan, and the emergency disposal cost was 15.803 million yuan.

\section{DISCUSSION}

The transformation of pollutants in the environment is a very complicated process. This evaluation is only based on the preliminary environmental investigation. Therefore, there is uncertainty in the conclusion of this environmental damage assessment.

On the one hand, due to scientific progress, technological development and technical staff cognitive lag, lack of technical capacity of the contradictions, may result in this incident the nature and extent of damage to the lack of awareness, identification and judgments are not in place, cannot accurately assess the nature and extent of environmental damage to the event; the other hand, due to the complexity of technical methods, as well as non-technical factors such as the psychological damage to the masses, management tools, inflation and other effects, the assessment of the amount of environmental damage are uncertain .

\section{REFERENCES}

Gong Chunming .The damage assessment of a waste oil contaminated site nces [ J ] . Ecotechnology, 2014(5): 29-28, 64.

Cai Feng;Zhao Shi-bo;Chen Gang-cai;Xian Si-shu;Yang Qing-ling;Zhou Xian-jie;Yuhai;A Method $R$ esearch on Environmental Damage Assessment of a Truck RolloverPollution Incident $[\mathrm{J}]$. Environmental Science, 2015: 1902-1910.

Li Erping, Li Jin, Qiu Yaqun, Pan Ying, Xiang Renjun.Identification and Evaluation of Environmental PollutionHazards of Waste Acid Drainage Contamination Case [J] .Environmental Science and Management,2008(12):159-162.

LI Jing;HAN Zhenchao;RONG Shaohui,A Case Study on Economic Loss Assessment of Environmental Pollution Accident [J] .Industrial Safety and Environmental Protection, 2013(12):10-12.

LI Haijie, Case Analysis and Thought of Environmental Pollution Damage Assessment [J] . Environment and Sustainable Development, 2013( 5) : 81-83.

$\mathrm{Yu}$ fang, Zhang hong, zhen, Niu kun yu ,ect, China's environmental damage assessment scope definition and evaluation methods [J] .Environmental Protection, 2012, (5) : 25-29.

Zhang qingwei, Economic Loss Assessment Studies of Environmental Pollution Accident [D] . Chongqing: Chongqing University, 2010.

Liu kewei, AStudy of Damage Assessmenton Ocean Environment and Eeosystem from Liquid Chemicals Transportation in Bulk [D] . Dalian:Dalian Maritime University, 2009.

Deng fengqiong, Discuss on assessment mechanisms of environmental pollution damage $[\mathrm{J}]$. Environmental Protection, 2014(8) : 41-42.

Liu qian,Guo hua, Wang jinnan, How to build the pollution damage to the environment assessment of judicial appraisal management system [J] . Environmental Protection, 2012, (5) : 35-38.

WU Yuxin, Environmental Litigation and Environmental Pollution Damage Identification [J] . Environment and Sustainable Development, 2013, 38(1) : 57-60.

Xu Wei,Li Yan,Li Min, Suggestions on economic losses assessment of environmental pollution accidents in Guizhou Province [J] . Environmental Protection and Technology, 2013, 19( 2) : 25-29. 